\title{
Choosing a strategic process in order to apply in Lean Six Sigma methodology for improving its performance using integrative approaches of BSC and DEA
}

\author{
Ardeshir Bazrkar \\ Soleyman Iranzadeh \\ Department of Industrial Management, East Azerbaijan Science and Research Branch, Islamic Azad \\ University, Tabriz, Iran. \\ Department of Management, Tabriz Branch, Islamic Azad University, Tabriz, Iran.
}

\begin{abstract}
Keywords
Process; Balanced scorecard; Data envelopment analysis; cross efficiency; Goal programming; Lean Six Sigma.
\end{abstract}

\begin{abstract}
Most of organizations use much of their focus and attention to solve problems, difficulties and weaknesses in their systems and processes to increase productivity and consequently to achieve sustainable competitive advantage in the global business arena. Organizations spend lots of time and resources to plan and develop their strategies; however most of them fail in the implementation of the strategy. Organizations try to achieve success through integrated performance of processes and technology to respond to the needs of their customers. Nowadays, application of Lean Six Sigma methodology is so applicable for organizations that operate in the competitive world. The importance of implementing the Lean Six Sigma in an organization is that the considered problem or process be discovered properly and selection of process beat the direction of organization's goals. In this way, organization can be targeted to take steps towards continuous improvement by improving the process performance.

The purpose of this research is choosing a strategic process through the Ghavamin Bank accounting group processes to improve the performance through application of Lean Six Sigma methodology. For this purpose, for selection of the process, first the criteria for choosing a strategic process were identified through six main measures of Balanced Scorecard and also by using the expert opinions. Consequently, information related to accounting group processes were collected through a database of Ghavamin Bank different units as well as interviews with Bank experts.Finally, using cross efficiency data envelopment analysis model, the performances of the processes were evaluated. The results showed that the process No. 18 ranked at the first place and it was introduced as the bank's strategic process to make continuous improvement in the Lean Six Sigma methodology.
\end{abstract}

Corresponding author: Soleyman Iranzadeh

Email address for corresponding author: Iranzadeh@iaut.ac.ir

First submission received: 3rd February 2017

Revised submission received: 28th February 2017

Accepted: 25th March 2017

\section{Introduction}

Conservation, sustainability as well as their development requires an on-time understanding of the environment opportunities and changes in the game rules. Organizations that can understand the new game rules have a better chance to benefit from the opportunities. New technologies, new perspectives and new methods can change the rules and to create entirely new game conditions. Organizations spend a lot of time and resources to plan and develop their strategies, but most of them fail at the implementation of the strategy.In 1982, results of a research in Fortune journal 
revealed that only $10 \%$ of well-formulated strategies are successfully carried out, and in other organizations, the strategy remains only as a written document (Kaplan and Norton, 2004 We know that the strategy is a macro and strategic plan and it is applied only when it is define and followed in the form of various projects. However, in recent years many organizations applied the improvement approaches such as Six Sigma and Lean Thinking and they tried to solve their problems using these approaches. Lean Six Sigma approach has three elements which make this methodology completely different and superior to other techniques of problem solving. These three elements include business strategy and quality assessment criteria, human infrastructure of Six Sigma methodology and being systematically. Nowadays, application of Lean Six Sigma methodology is so applicable for organizations that operate in the competitive world. Six Sigma approach is primarily a way to improve the capability of business processes using statistical tool, which aims to reduce defects and to improve the profitability, employee satisfaction, product quality and finally customer satisfaction. Also, application of lean thinking reduces costs and eliminates non-valuable activities of the organizations (Wang and Chean, 2010).

In order to use the benefits of Lean Six Sigma projects, the organizations should act in such a way that these projects be in line with the strategic objectives of the organization. Organizations should choose projects that meet the organization's strategic requirements and be consistent with the company's objective which is reflected in its strategy. The purpose of this research is choosing a strategic process through the Ghavamin Bank accounting group processes to improve the performance through application of Lean Six Sigma methodology. In fact, the goal is achieving continuous improvement in process performance in line with the Bank's overall strategy. For this purpose, a process is selected to have the highest score based on six perspectives of Balanced Scorecard through cross efficiency score in DEA, and thus improving the performance of this process which is selected based on strategic measures, can improve the performance of services according to the bank's strategic themes and create continues improve in the processes of Ghavamin Bank.

\section{Literature review}

\section{2-1. Strategic themes}

Senior managers almost always discriminate their strategies into several key themes (issues). Generally, strategic themes reflect what the management team believes must be done to be succeed. Financial sectors and customers usually express the results which is desirable for internal stakeholders (shareholders and employees) and external stakeholders (customers, suppliers and society). Strategic themes don't reflect the financial results such as improvement in the considered values by the shareholders, or customer results such as more keeping the customers, and more market share. These themes reflect the views of senior managers about what should be done inside the company to achieve the strategic results. So, these themes generally are related to the internal business processes (Kaplan and Norton, 2004). Internal processes create and provide the value to the customers. Performance of this area is a leading indicator to support the subsets. Also, the objectives of growth and learning perspective, describe the integration of people, technology and other relevant organizations to support the strategy. Improvement in learning and growth criteria is a leading indicator for other three areas. A company must focus on several important internal processes that provide distinctive values to the customers and are more important to enhance productivity and to secure the organizations franchise.

\section{2-2. Balanced Scorecard}

Balanced scorecard or BSC was developed by the study Kaplan and Norton in 1990.Balanced Scorecard which has attracted nowadays a lot of attention, is not only a comprehensive and integrated performance measurement tool, but also a management system with a new approach of strategic management and was introduced in the nineties.Norton and Kaplan with the introduction of the performance evaluation system drew managers' attention to the fact that it is much better to consider the employees' performance with a more general approach. They introduced their theory 
with four dimensions or aspects which have been developed to six dimensions or aspects in this study. Another index of Norton and Kaplan, entitled the strategy map, investigates the importance of employee satisfaction and the environment and the community (Communication). The last two aspects are important in this respect that they have integrated the main factors in the Balanced Scorecard (Rezai and Hosseini, 2011). In this study, criteria and indicators to evaluate the processes in the Ghavamin Bank accounting group were defined based on the Balanced Scorecard measures. For this purpose, with regard to the six main measures of the Balanced Scorecard, after reviewing the literature and interviewing with experts of Ghavamin bank, selected indicators related to each measure were identified using the group name technique. Table 1 presents indicators for each of these measures with regard to investigated processes.

Table 1: Key Indicators with respect to six perspectives of Balanced Scorecard

\begin{tabular}{|c|c|c|}
\hline $\begin{array}{l}\begin{array}{c}\text { Environment and community perspective } \\
\text { (communications): }\end{array} \\
\text {-Alignment with major social strategy and } \\
\text { social needs } \\
\text {-Compliance with environmental laws }\end{array}$ & $\begin{array}{l}\text { Customer perspective: } \\
\text {-The number of } \\
\text { customers } \\
\text {-Repetition rate of } \\
\text { customer service }\end{array}$ & $\begin{array}{l}\text { Financial perspective: } \\
\text {-Direct revenue } \\
\text {-Direct costs }\end{array}$ \\
\hline $\begin{array}{c}\text { Learn and grow: } \\
\text {-Staff training hours } \\
\text {-Number of employees with advanced degree }\end{array}$ & $\begin{array}{l}\text { Employee satisfaction: } \\
\text {-Number of complaints of } \\
\text { staff } \\
\text {-Staff movement rate }\end{array}$ & $\begin{array}{l}\text { Internal processes: } \\
\text {-Rate of labor use } \\
\text {-Response times to } \\
\text { customer requests }\end{array}$ \\
\hline
\end{tabular}

\section{2-3. Lean Six Sigma}

Six Sigma and Lean Thinking are both problem solving tools. Proper use of these tools can effectively fix the problem and also have role in improvements of the organization status. To this end, organizations must have a proper understanding of their issues and problems; and also be aware of the nature and mode of operation of these tools. Lean Six Sigma is an effective methodology to accelerate the improvement of product and service quality (Kwak and Anbari, 2004).Organizational planning, which wants to follow this approach, is firstly entering into the field of sigma, and then passing the improvement steps to reach the Six Sigma level. The basic concept of lean thinking lies in eradicating wasting and creation of value for the organizations. Six Sigma methodologies give the opportunity to the organizations to minimize the process errors by using this methodology. Simultaneous implementing, applying and benefiting of both systematic lean thinking and Six Sigma methodology can be as strategic plans of most organizations and businesses to achieve their core objective which is creating added values for the customers. The influence of applying Lean Six Sigma for improving the organization's processes is undeniable (Shah et aI., 2008). The purpose of Lean Six Sigma is growing and these growths not only reduce the costs, but also increase the productivity (Bryne et al., 2007).

\section{2-5. Cross efficiency model in DEA}

Data envelopment analysis (DEA) is a methodology to measure the relative efficiency of similar decision making units (DMUs) with several input and output indicators (Charnes et al., 1978).The DMUs can bank branches, hospitals, factories, etc. (Cook, 2009).Cross efficiency evaluation method is an extension of DEA, which can be used to identify the best practices and rank the decision making units by using the cross efficiency score (Sexton et al, 1986). However as Doyle and Green (1994) reported, lack of uniqueness of the optimal weights of DEA may reduce the beneficiary of cross efficiency of DEA.

Sexton et al. (1986) and Doyle and Green (1994) proposed using the secondary objectives to fix the problem of non-unique results. They presented the hostile and friendly model formulations. In this regard, several other secondary objective have been presented (Rodder and Reucher, 2011; Liang et al., 2008; Moeini et al., 2015). 


\section{2-5-1. Cross efficiency ranking model}

Suppose that there are $n$ DMUs that they produce $s$ outputs by taking inputs. Also $i^{\text {thinput }}$ and $r^{\text {th }}$ output of DMUjare presented byx $x_{\mathrm{ij}}$ and $\mathrm{y}_{\mathrm{r} j}$, respectively. Charnes et al. (1978) presented the following multiple CCR model to evaluate the performance of $\mathrm{DMU}_{\mathrm{d}}$ :

$$
E_{d d}^{*}=\max \frac{\sum_{r=1}^{s} u_{r} y_{r d}}{\sum_{i=1}^{m} v_{i} x_{i d}}
$$

\section{$S t$}

$$
\begin{aligned}
& \frac{\sum_{r=1}^{s} u_{r} y_{r j}}{\sum_{i=1}^{m} v_{i} x_{i j}} \leq 1, \quad j=1, \ldots, \mathrm{n} \\
& u_{r} \geq \circ, \quad v_{i} \geq \circ, \quad \forall r, i
\end{aligned}
$$

The optimum value of model (1) is less than or equal to $1 . \mathrm{DMU}_{\mathrm{d}}$ is efficient if the optimal value of model (1) is 1 . Otherwise, the unit is inefficient.Suppose that $\left(u^{d}, v^{d}\right)$ are optimal weight for $\mathrm{DMU}_{\mathrm{d}}$ using CRR model. In this case, the cross efficiency score of $\mathrm{DMU}_{\mathrm{j}}$ according to optimal weights of $\mathrm{DMU}_{\mathrm{d}}$ is calculated as follows:

$$
E_{d j}=\frac{\sum_{r=1}^{s} u_{r}^{d} y_{r j}}{\sum_{i=1}^{m} v_{i}^{d} x_{i j}}
$$

Cross efficiency score for each unit is calculated using the following equation:

$E_{d}=\frac{\sum_{j=1} E_{j d}}{n}$

\section{2-5-2 Secondary objective in DEA}

Like basic multiple models in DEA, model (1) has also multiple optimal solutions. The multiple optimal solution of model (1) creates a different cross efficiency matrix. To solve this problem and to obtain a unique cross efficiency matrix, a secondary objective model is defined. The presented model is based on maintaining the efficiency of decision making units under evaluation, indicating that maximizing the performance of $D M U_{d}$ and other units are at the same time.In fact, the objective is to maximize the efficiency of n- 1 units simultaneously. For this purpose, we use a multi-objective model with n-1 objective functions; so that, every objective function corresponds to the efficiency of a single decision making unit; so, the secondary objective model will be as follows:

$$
\begin{array}{r}
\max \frac{\sum_{r=1}^{s} u_{r} y_{r 1}}{\sum_{i=1}^{m} v_{i} x_{i 1}} \\
\max \frac{\sum_{r=1}^{s} u_{r} y_{r 2}}{\sum_{i=1}^{m} v_{i} x_{i 2}}
\end{array}
$$




$$
\begin{aligned}
& \max \frac{\sum_{r=1}^{s} u_{r} y_{r m}}{\sum_{i=1}^{m} v_{i} x_{i n}} \\
& S t \\
& \frac{\sum_{r=1}^{s} u_{r} y_{r j}}{\sum_{i=1}^{m} v_{i} x_{i j}} \leq 1, \quad j=1, \ldots, \mathrm{n} \\
& \sum_{r=1}^{s} u_{r} y_{r d} \\
& \sum_{i=1}^{m} v_{i} x_{i d} \\
& u_{r} \geq \circ, \quad v_{i} \geq \circ, \quad \forall r, i
\end{aligned}
$$

Above model is a multi-objective problem (Ehrgott, 2000). The purpose of this model is maintaining the efficiency of $D M U_{d}$ and maximizing the performance of other DMUs simultaneously. In fact, this model is a secondary objective model with friendly approach. The first constraints in model (2) added to maintain the efficiency of $D M U_{d}$. The model can be minimized instead of maximization. This type of model would be a hostile target model; because in this case, the model seeks to minimize the efficiency of other DMUs. There are several ways for solving the model (2) in multi-objective problems.

In all methods the aim is to convert a multi-objective problem into a single-objective problem and solving it using mathematical programming methods (Ehrgott, 2000).Here we use the goal programming method for solving this multi-objective model. In fact, the multi-objective model (2) is converted as follows:

$$
\begin{aligned}
& \min \sum_{\substack{j=1 \\
j \neq d}}^{n} s_{2 j} \\
& S t \\
& \sum_{r=1}^{s} u_{r} y_{r j} \\
& \frac{\sum_{r=1} u_{i=1} v_{i}}{\sum_{i j}^{m} v_{i} x_{i j}} \leq 1, \quad j=1, \ldots, \mathrm{n} \\
& \frac{\sum_{r=1}^{s} u_{r} y_{r j}}{\sum_{i=1}^{m} v_{i} x_{i j}}+s_{1 j}-s_{2 j}=1, \quad j=1, \ldots, \mathrm{n} ; j \neq d \\
& \frac{\sum_{r=1}^{s} u_{r} y_{r d}}{\sum^{m} v_{i} x_{r d}}=E_{d d}^{*} \\
& \sum_{i=1}^{m} v_{i} x_{i d}
\end{aligned}
$$


$u_{r} \geq \circ, \quad v_{i} \geq \circ, \quad \forall r, i$

Here we consider the idea (1) which is being efficient for the DMU. Where, $(j=1, \ldots, \mathrm{n} ; j \neq d) s_{2 j}, s_{1 j}$ are positive and negative deviation variables, respectively.

Now, if $\left(v^{*}, \mathrm{u}^{*}\right)$ be the optimal solution for model (3), then with considering the optimal weights of $D M U_{d}$, the cross efficiency score of $D M U_{k}$ is as follows:

$$
E_{d k}=\frac{\sum_{r=1}^{s} u_{r}^{*} y_{r k}}{\sum_{i=1}^{m} v_{i}^{*} x_{i k}}, \quad k=1, \ldots, n ; k \neq d
$$

Finally, using the same process as previous section, cross efficiency matrix and cross efficiency score of all DMUs can be calculated.

\section{Research methodology}

The methodology of this research is a descriptive. The aim of this study is to provide a framework for selecting a strategic process that is selected among the processes of Ghavamin bank accounting services group to improve the process performance and to enhance the service efficiency of Ghavamin Bank.

For this purpose, after investigating six measures of balanced scorecard and reviewing previous studies and Ghavamin bank processes, finally 12 sub-criteria were identified based on 6 main measures by using the group name technique and interviewing with 5 experts of bank accounting services. Then, to be able to use cross efficiency technique of DEA to rank the processes and to select the strategic process for using in Lean Six Sigma process, the following criteria were divided into two groups of inputs and outputs. Dividing the criteria into input and output is due to the use of DEA model. Regarding the nature of the input and output, information and data related to processes and criteria are provided in Table 2. In this table, each of the 25 examined processes in the Ghavamin bank accounting group were defined as a decision making unit (DMU).

And information on each of these processes and criteria were collected from the statistics group database, human resources and organization and methods will be collected in Ghavamin Bank.It should be noted that 10 criteria are metric quantitative and 2 criteria are qualitative. To collect information related to two qualitative criteria (compliance with environmental laws and compatibility with major social strategy) of the experts, Likert scale was used.

Table 2: Information on the balanced scorecard criteria for selection of the strategic process of DMUs

\begin{tabular}{|c|c|c|c|c|c|c|c|c|c|c|c|c|}
\hline \multirow{3}{*}{$\begin{array}{l}\text { DMUs } \\
\text { (Proce } \\
\text { sses) }\end{array}$} & \multicolumn{2}{|c|}{$\begin{array}{l}\text { Financial } \\
\text { perspective }\end{array}$} & \multicolumn{2}{|c|}{$\begin{array}{l}\text { Customer } \\
\text { perspective }\end{array}$} & \multicolumn{2}{|c|}{$\begin{array}{l}\text { Internal process } \\
\text { perspective }\end{array}$} & \multicolumn{2}{|c|}{$\begin{array}{l}\text { learning and } \\
\text { growth } \\
\text { perspective }\end{array}$} & \multicolumn{2}{|c|}{$\begin{array}{l}\text { Employee } \\
\text { satisfaction } \\
\text { perspective }\end{array}$} & \multicolumn{2}{|c|}{$\begin{array}{l}\text { Environment and } \\
\text { society } \\
\text { perspectives }\end{array}$} \\
\hline & $\begin{array}{l}\text { Direct } \\
\text { cost }\end{array}$ & $\begin{array}{l}\text { Direct } \\
\text { income }\end{array}$ & $\begin{array}{l}\text { Numb } \\
\text { er of } \\
\text { custo } \\
\text { mers }\end{array}$ & $\begin{array}{l}\text { Repetiti } \\
\text { on } \\
\text { service } \\
\text { rate }\end{array}$ & $\begin{array}{l}\text { Labor } \\
\text { rate }\end{array}$ & $\begin{array}{l}\text { Respons } \\
\text { e time to } \\
\text { custome } \\
\mathrm{r}\end{array}$ & $\begin{array}{l}\text { Employ } \\
\text { ee } \\
\text { training } \\
\text { hours }\end{array}$ & $\begin{array}{l}\text { Number } \\
\text { of } \\
\text { employe } \\
\text { es with } \\
\text { higher } \\
\text { degree }\end{array}$ & $\begin{array}{l}\text { Number } \\
\text { of staff } \\
\text { moveme } \\
\text { nt }\end{array}$ & $\begin{array}{l}\text { Number } \\
\text { of staff } \\
\text { complai } \\
\text { nts }\end{array}$ & $\begin{array}{l}\text { Environ } \\
\text { mental } \\
\text { regulati } \\
\text { ons } \\
\text { complia } \\
\text { nce }\end{array}$ & $\begin{array}{l}\text { Align } \\
\text { with } \\
\text { major } \\
\text { social } \\
\text { strategie } \\
\text { s }\end{array}$ \\
\hline & Input & Output & Input & Output & Input & Output & Input & Output & Input & Output & Input & Output \\
\hline 1 & 1138280 & 690000 & 30 & 2.4 & 0.027 & 386 & 2 & 5 & 0.13 & 0.17 & 5 & 5 \\
\hline 2 & 1436080 & 320000 & 40 & 2.1 & 0.024 & 1290 & 2 & 5 & 0.13 & 0.33 & 5 & 3 \\
\hline 3 & 2557200 & 400000 & 80 & 2.12 & 0.017 & 2760 & 2 & 5 & 0.13 & 0.17 & 4 & 3 \\
\hline
\end{tabular}




\begin{tabular}{ccccccccccccc}
4 & 2571624 & 252000 & 72 & 2.25 & 0.012 & 2790 & 1 & 5 & 0.13 & 0.5 & 3 & 3 \\
5 & 105784 & 60000 & 6 & 3.33 & 0.1 & 118 & 1 & 5 & 0.13 & 0.33 & 1 & 3 \\
6 & 199248 & 144000 & 12 & 2.5 & 0.033 & 222 & 1 & 5 & 0.13 & 0.33 & 1 & 3 \\
7 & 115395 & 350000 & 7 & 3 & 0.095 & 126 & 2 & 5 & 0.13 & 0.17 & 3 & 4 \\
8 & 884504 & 415000 & 83 & 1.67 & 0.014 & 944 & 1 & 5 & 0.13 & 0.17 & 1 & 3 \\
9 & 1496000 & 300000 & 300 & 1.33 & 0.0025 & 1700 & 0.5 & 5 & 0.13 & 0.33 & 4 & 5 \\
10 & 6167400 & 7500000 & 750 & 1.093 & 0.0012 & 6180 & 2 & 5 & 0.13 & 0.17 & 5 & 3 \\
11 & 6843250 & 1875000 & 1250 & 1.12 & 0.0007 & 6400 & 1 & 5 & 0.13 & 0.17 & 5 & 3 \\
12 & 5326000 & 2500000 & 500 & 1.5 & 0.002 & 5500 & 1 & 5 & 0.13 & 0.5 & 4 & 4 \\
13 & 557160 & 810000 & 90 & 1.66 & 0.0066 & 600 & 2 & 5 & 0.13 & 0.5 & 3 & 2 \\
14 & 53632 & 100000 & 4 & 2.25 & 0.11 & 58 & 1 & 5 & 0.13 & 0.66 & 1 & 2 \\
15 & 1116200 & 750000 & 50 & 1.9 & 0.021 & 1250 & 1 & 5 & 0.13 & 0.33 & 5 & 1 \\
16 & 1005000 & 1500000 & 250 & 1.2 & 0.033 & 1050 & 0.5 & 5 & 0.13 & 0.33 & 3 & 3 \\
17 & 8469000 & 1250000 & 2500 & 1.12 & 0.0003 & 7800 & 1 & 5 & 0.13 & 0.17 & 3 & 3 \\
18 & 1614000 & 2000000 & 500 & 1.25 & 0.0015 & 1650 & 0.5 & 5 & 0.13 & 0.17 & 4 & 4 \\
19 & 7382000 & 1500000 & 3000 & 1.066 & 0.0003 & 6200 & 0.5 & 5 & 0.13 & 0.5 & 3 & 3 \\
20 & 2480600 & 3000000 & 300 & 1.33 & 0.0025 & 2600 & 1 & 5 & 0.13 & 0.33 & 4 & 3 \\
21 & 178540 & 875000 & 35 & 1.43 & 0.02 & 190 & 1 & 5 & 0.13 & 0.66 & 3 & 2 \\
22 & 8040000 & 5750000 & 250 & 1.2 & 0.003 & 1850 & 2 & 5 & 0.13 & 0.5 & 5 & 2 \\
23 & 3140000 & 500000 & 1000 & 1.2 & 0.0008 & 3200 & 1 & 5 & 0.13 & 0.33 & 2 & 3 \\
24 & 1362008 & 99900 & 222 & 1.8 & 0.005 & 1466 & 1 & 5 & 0.13 & 0.17 & 2 & 3 \\
25 & 8044500 & 1500000 & 1500 & 1 & 0.0006 & 7500 & 2 & 5 & 0.13 & 0.5 & 5 & 4 \\
\hline
\end{tabular}

\section{Analysis of the research results}

Considering that in this study, ranking and selection of strategic process are done in Lean Six Sigma using measures of Balanced Scorecard and cross efficiency approach in DEA, ranking accounting group processes in line with selection of strategic process by using the cross efficiency approach has the following steps:

1. In the first stage model 1 is run for all of the DMUs;

2. In the second stage ideal programming model 3 is run for all of the DMUs;

3. In the third stage if $\left(v^{*}, \mathrm{u}^{*}\right)$ is the optimal solution of model 3 , then considering the $D M U_{d}$ optimal weights, $D M U_{k}$ cross efficiency presented as follows:

$$
E_{d k}=\frac{\sum_{r=1}^{s} u_{r}^{*} y_{r k}}{\sum_{i=1}^{m} v_{i}^{*} x_{i k}}, \quad k=1, \ldots, n ; k \neq d
$$

4. At the fourth stage, the cross efficiency index for DMU $\mathrm{d}$ is as follows.

$$
E_{\mathrm{d}}=\frac{\sum_{j=1} E_{j d}}{n}
$$

5. In the fifth step, cross efficiency of the accounting group processes are ranked. Results cross efficiency score for the processes of Ghavamin Bank accounting group presented in Table 3. 
Table 3: Cross efficiency score of processes for the Ghavamin Bank Accounting group based on the Balanced Scorecard

\begin{tabular}{|c|c|c|c|c|c|c|c|c|c|c|c|c|c|c|c|c|c|c|c|c|c|c|c|c|}
\hline & 1 & 2 & 3 & 4 & 5 & 6 & 7 & 8 & 9 & 10 & 12 & 13 & 14 & 15 & 16 & 17 & 18 & 19 & 20 & 21 & 22 & 23 & 24 & 25 \\
\hline 1 & 1 & 0.77 & 0.41 & 0.3 & 0.16 & 0.2 & 0.55 & 0.2 & 0.65 & 32 & 0.31 & 0.27 & 0.7 & 0.24 & 0.82 & 0.67 & 0.15 & 0.68 & 0.19 & 0.49 & 1 & 0.8 & 0.22 & 0.31 \\
\hline 2 & 1 & 1 & 0.79 & 0.59 & 0.2 & 0.2 & 0.6 & 0.2 & 0.8 & 1 & 0.99 & 0.79 & 0.59 & 0.19 & 1 & 0.59 & 0.59 & 0.8 & 0.59 & 0.8 & 0.59 & 0.99 & 0.4 & 0.4 \\
\hline 3 & 1 & 1 & 1 & 1 & 1 & 1 & 1 & 1 & 1 & 1 & 1 & 1 & 1 & 1 & 1 & 1 & 1 & 1 & 1 & 1 & 1 & 1 & 1 & 1 \\
\hline 4 & 1 & 1 & 0.98 & 1 & 1 & 1 & 1 & 1 & 1 & 0.99 & 1 & 1 & 1 & 1 & 0.99 & 1 & 1 & 1 & 1 & 1 & 1 & 1 & 1 & 1 \\
\hline 5 & 0.16 & 0.11 & 0.1 & 0.09 & 0.76 & 0.47 & 0.9 & 0.3 & 0.56 & 0.3 & 0.45 & 0.24 & 0.47 & 1 & 0.12 & 0.67 & 0.72 & 0.8 & 1 & 0.32 & 0.72 & 0.08 & 0.79 & 0.44 \\
\hline 6 & 0.16 & 0.11 & 0.1 & 0.09 & 0.76 & 0.47 & 0.9 & 0.3 & 0.56 & 0.3 & 0.45 & 0.25 & 0.47 & 1 & 0.12 & 0.67 & 0.73 & 0.8 & 1 & 0.32 & 0.72 & 0.08 & 0.79 & 0.44 \\
\hline 7 & 0.18 & 0.13 & 0.08 & 0.06 & 0.35 & 0.23 & 1 & 0.12 & 0.21 & 0.17 & 0.15 & 0.35 & 0.35 & 0.71 & 0.2 & 0.33 & 0.2 & 1 & 0.28 & 0.19 & 0.91 & 0.08 & 0.23 & 0.15 \\
\hline 8 & 0.89 & 0.57 & 0.59 & 0.42 & 0.73 & 0.77 & 1 & 1 & 0.8 & 0.38 & 0.38 & 0.35 & 0.49 & 0.45 & 0.56 & 0.77 & 0.32 & 1 & 0.28 & 0.55 & 0.46 & 0.23 & 0.5 & 0.87 \\
\hline 9 & 0.3 & 0.18 & 0.18 & 0.31 & 0.31 & 0.32 & 0.24 & 0.35 & 0.1 & 0.19 & 0.36 & 0.43 & 0.12 & 0.2 & 0.11 & 0.6 & 0.36 & 0.86 & 0.56 & 0.34 & 0.21 & 0.12 & 0.34 & 0.35 \\
\hline 10 & 0.37 & 0.44 & 0.34 & 0.24 & 0.05 & 0.07 & 0.18 & 0.11 & 0.54 & 1 & 0.84 & 0.92 & 0.33 & 0.08 & 0.47 & 0.47 & 0.5 & 1 & 0.53 & 0.59 & 0.38 & 0.86 & 0.3 & 0.19 \\
\hline 11 & 0.48 & 0.53 & 0.42 & 0.31 & 0.07 & 0.09 & 0.23 & 0.15 & 0.75 & 0.89 & 1 & 0.6 & 0.41 & 0.1 & 0.62 & 0.63 & 0.82 & 0.82 & 1 & 0.69 & 0.5 & 0.74 & 0.51 & 0.28 \\
\hline 12 & 0.02 & 0.01 & 0.01 & 0.007 & 0.002 & 0.003 & 0.007 & 0.01 & 0.01 & 0.38 & 0.09 & 1 & 0.03 & 0.002 & 0.002 & 0.007 & 0.006 & 1 & 0.08 & 0.13 & 0.03 & 0.26 & 0.02 & 0.003 \\
\hline 13 & 0.98 & 0.87 & 0.64 & 0.48 & 0.62 & 0.74 & 1 & 0.8 & 0.9 & 0.42 & 0.38 & 0.37 & 0.92 & 0.65 & 1 & 1 & 0.25 & 0.99 & 0.27 & 0.68 & 1 & 0.31 & 0.47 & 0.75 \\
\hline 14 & 0.1 & 0.07 & 0.03 & 0.03 & 0.49 & 0.27 & 0.73 & 0.07 & 0.06 & 0.04 & 0.02 & 0.14 & 0.17 & 1 & 0.1 & 0.11 & 0.01 & 0.39 & 0.01 & 0.06 & 0.55 & 0.03 & 0.02 & 0.04 \\
\hline 15 & 0.2 & 0.17 & 0.12 & 0.1 & 0.44 & 0.3 & 1 & 0.24 & 0.54 & 0.3 & 0.43 & 0.23 & 0.54 & 0.78 & 0.24 & 0.66 & 0.67 & 0.78 & 0.92 & 0.32 & 1 & 0.09 & 0.73 & 0.41 \\
\hline 16 & 0.52 & 0.49 & 0.46 & 0.49 & 0.4 & 0.52 & 0.43 & 0.69 & 1 & 0.56 & 0.64 & 0.6 & 0.58 & 0.53 & 0.52 & 1 & 0.68 & 1 & 0.83 & 0.73 & 0.78 & 0.42 & 0.81 & 0.64 \\
\hline 17 & 0.2 & 0.17 & 0.12 & 0.1 & 0.48 & 0.33 & 1 & 0.26 & 0.57 & 0.32 & 0.46 & 0.25 & 0.56 & 0.82 & 0.24 & 0.69 & 0.72 & 0.83 & 1 & 0.34 & 1 & 0.09 & 0.79 & 0.44 \\
\hline 18 & 0.04 & 0.02 & 0.01 & 0.009 & 0.04 & 0.06 & 0.24 & 0.04 & 0.02 & 0.1 & 0.03 & 0.37 & 0.12 & 0.15 & 0.05 & 0.13 & 0.03 & 1 & 0.04 & 0.1 & 0.4 & 0.05 & 0.03 & 0.01 \\
\hline 19 & 0.08 & 0.07 & 0.08 & 0.07 & 0.16 & 0.16 & 0.24 & 0.24 & 0.49 & 0.32 & 0.45 & 0.32 & 0.43 & 0.24 & 0.12 & 0.64 & 0.72 & 1 & 1 & 0.32 & 0.59 & 0.09 & 0.78 & 0.4 \\
\hline 20 & 0.2 & 0.16 & 0.12 & 0.1 & 0.53 & 0.36 & 1 & 0.28 & 0.57 & 0.33 & 0.46 & 0.31 & 0.55 & 0.86 & 0.22 & 0.71 & 0.72 & 1 & 1 & 0.35 & 1 & 0.01 & 0.79 & 0.44 \\
\hline 21 & 0.18 & 0.15 & 0.1 & 0.08 & 0.51 & 0.34 & 0.96 & 0.23 & 0.45 & 0.28 & 0.36 & 0.32 & 0.5 & 0.96 & 0.23 & 0.59 & 0.59 & 1 & 0.77 & 0.3 & 1 & 0.09 & 0.62 & 0.35 \\
\hline 22 & 0.5 & 0.55 & 0.42 & 0.3 & 0.07 & 0.09 & 0.24 & 0.15 & 0.72 & 0.93 & 0.95 & 0.73 & 0.44 & 0.1 & 0.61 & 0.63 & 0.63 & 1 & 1 & 0.7 & 0.52 & 1 & 0.52 & 0.28 \\
\hline 23 & 0.18 & 0.13 & 0.11 & 0.1 & 0.71 & 0.45 & 1 & 0.29 & 0.57 & 0.31 & 0.45 & 0.24 & 0.5 & 1 & 0.17 & 0.68 & 0.68 & 0.82 & 1 & 0.33 & 0.84 & 0.08 & 0.79 & 0.44 \\
\hline 24 & 1 & 0.51 & 0.99 & 0.34 & 0.51 & 0.51 & 1 & 1 & 0.51 & 0.99 & 0.99 & 0.34 & 0.34 & 0.25 & 0.51 & 0.51 & 0.99 & 1 & 0.34 & 0.51 & 0.25 & 0.34 & 0.51 & 1 \\
\hline 25 & 0.2 & 0.17 & 0.12 & 0.1 & 0.48 & 0.33 & 1 & 0.26 & 0.17 & 0.32 & 0.46 & 0.25 & 0.56 & 0.82 & 0.24 & 0.69 & 0.72 & 0.83 & 1 & 0.34 & 1 & 0.09 & 0.79 & 0.44 \\
\hline $\mathrm{Ed}$ & $\begin{array}{c}0.43 \\
76\end{array}$ & 0.3752 & 0.3328 & 0.26864 & 0.43328 & 0.37132 & 0.69788 & 0.3716 & 0.542 & 0.4856 & 0.524 & 0.4668 & 0.4868 & 0.56528 & 0.41048 & 0.61788 & 0.55224 & 0.896 & 0.6676 & 0.46 & 0.698 & 0.3572 & 0.55 & 0.44292 \\
\hline
\end{tabular}


In addition to cross efficiency matrix, Table 3 also presents the cross efficiency index which is the average of individual columns data in this table. It is evident that if the processes of Ghavamin Bank Accounting group are ranked based on this index, the ranking will be without any interference. So, it is possible to make the best choice among the examined processes to identify strategic process for applying the process in Lean Six Sigma. Table (4) presents the processes ranking of Ghavamin Bank Accounting group in order to choose the strategic process according to cross efficiency score of data envelopment analysis.

Table 4: Ranking the bank processes according to cross efficiency score

\begin{tabular}{|c|c|c|}
\hline Process No. & Cross efficiency score & Process rank \\
\hline 1 & 0.4376 & 17 \\
\hline 2 & 0.3752 & 20 \\
\hline 3 & 0.3328 & 24 \\
\hline 4 & 0.26864 & 25 \\
\hline 5 & 0.43328 & 18 \\
\hline 6 & 0.37132 & 22 \\
\hline 7 & 0.69788 & 3 \\
\hline 8 & 0.3716 & 21 \\
\hline 9 & 0.542 & 9 \\
\hline 10 & 0.4856 & 13 \\
\hline 11 & 0.524 & 10 \\
\hline 12 & 0.4668 & 14 \\
\hline 13 & 0.4868 & 12 \\
\hline 14 & 0.56528 & 6 \\
\hline 15 & 0.4148 & 19 \\
\hline 16 & 0.61788 & 5 \\
\hline 17 & 0.55224 & 7 \\
\hline 18 & 0.896 & 1 \\
\hline 19 & 0.6676 & 4 \\
\hline 20 & 0.46 & 15 \\
\hline 21 & 0.698 & 2 \\
\hline 22 & 0.3572 & 23 \\
\hline 23 & 0.55 & 8 \\
\hline 24 & 0.44292 & 16 \\
\hline 25 & 0.4908 & 11 \\
\hline
\end{tabular}

According to the results, process number 18 has the highest efficiency score and it is the first priority is to choose. Also, other processes in terms of strategic indicators of balanced scorecard are the secondary priorities.

\section{Discussions and conclusions}

The aim of this research was to select a strategic process to use in Lean Six Sigma methodology and to finally improve the performance of using the hybrid approach BSC \& DEA. For this purpose, after detecting the selection criteria, the strategic process was selected based on six measures of balanced scorecard. Consequently, information related to accounting group processes were collected through a database of Ghavamin Bank different units as well as interviews with Bank experts. Finally, using cross efficiency data envelopment analysis model, the performances of the processes were evaluated. The results showed that process number 18 has the highest efficiency score and it is the first priority is to choose and accordingly, this process was identified in Ghavamin Bank Accounting group processes. Also, the process number 4 has the last place in priority. The notable point in this ranking method compared to traditional methods of DEA is that in this way, all 
processes have been ranked with no restriction. However, if we use the traditional models, efficiency score of all processes will be equal to 1 and it is not possible to rank the processes and other methods of rankings such as Anderson-Peterson (AP) must be used. In addition as previously explained, in this way all of the processes affect in ranking and it is avoided from self-assessment or evaluation in the best condition, which is the characteristic of DEA. When using DEA it is assumed that, the process should be 3 times higher than the number of indicators, to achieve an appropriate analysis.

Given that we have 12 indexes, the number of processes should be more than 36 , while it is less than 36. To fix the problem in DEA in some cases weight restrictions model is used. However, the presented model has no problem and there is no need to use weight restrictions model. In this approach, the one with the most score earned is identified as efficient unit. In this study process number 18 was identified as the most efficient process. As selection of this process was based on the Balanced Scorecard strategic indicators, it can be identified as a strategic process to apply in Lean Six Sigma methodology.

\section{Research limitations and direction for further research 6.1 Research limitations}

In this research, we have been under various restrictions. The most important restriction was associated to recognition and presentation of the strategic indexes of Ghavamin bank from the view of bank's specialists. Of other particular restrictions of the research we can mention the limitations corresponding to the six perspective of BSC and mentioned processes of bank's accounting group.

\section{2 directions for further research}

In this study, we have used a combination approach including BSC and Cross efficiency in DEA in choosing a strategic process in order to apply in Lean Six Sigma methodology. For future studies, we recommend implementing other strategic models, such as SWOT, and decision making models of MCDM and MODM.

\section{References}

Kaplan, Robert S. Norton, David P. 2004. Strategy-focused organization. Translated by Bakhtiyari, P. First edition, Tehran: Management industry organization.

Rezaee, Gh.,AghaSeyedHosseini, S.M. 2011. Twelve Steps to develop and implement a Balanced Scorecard and determining the performance indicators. First Edition.Bergapublication, Tehran, Iran.

Byrne, G. Lubowe, D. Blitz, A.2007. Using a Lean Six Sigma approach to drive innovation. Journal of Strategy and Leadership,35(2):5-10.

Charnes, A., Cooper, W., Rhodes, E. 1978. Measuring the efficiency of decision making units. European Journal of Operational Research, 2:429-444.

Kwak, Y.H. Anbari, F.T. 2004.Benefits, obstacles and future of six sigma approach. Tec novation,20:18.

Liang, L., Wu, J.,Cook, W.,Zhu, J. 2008. Alternative secondary goals in DEA cross efficiency evaluation. International Journal of Production Economics, 36:1025-1030.

Ehrgott,M. 2000.Multicriteria Optimization. Volume 491:LectureNotes inEconomics and Mathematical Systems, Springer-Verlag, Berlin.

Moeini, M., Karimi, B., Khorram, E. 2015.A Cross-Efficiency Approach for Evaluating Decision Making Units in Presence of Undesirable Outputs. In book: Modelling, Computation and Optimization in Information Systems and Management Sciences, Springer:487-498.

Shah, R., Chandrasekaran,A., Linderman, K. 2008.In pursuit of implementation patterns: The context of Lean and Six Sigma. International Journal of Production Research,46(23):6679-6699.

Sexton, T.R., Silkman, R.H., Hogan, A.J.1986. Data envelopmentanalysis: Critique and extensions. In: Silkman, R.H.(Ed.), of Data Measuring Efficiency: An Assessment EnvelopmentAnalysis, 32,Jossey-Bass, San Francisco: 73-105. 
Cook, W., Seiford, L. M. 2009. Data envelopment analysis (DEA): Thirty years on. European Journal of Operational Research, 34:1-17.

Wang, F.K., Chen, K.SH. 2010. Applying Lean Six Sigma and TRIZ methodology in banking services. Total Quality Management,21(3):301-315.

Rodder, W., Reucher, E. 2012.Advanced x-efficiencies for CCR and BCC models: towards peer-based DEA controlling. European Journal of Operational Research 37:467-476.

Rodder, W., Reucher, E. 2011.A consensual peer-based DEA-model with optimized cross-efficiencies: input allocation instead of radial reduction. European Journal of Operational Research, 36:148154. 